AUTHOR CORRECTION

\title{
Author Correction: Altered oral and gut microbiota and its association with SARS-CoV-2 viral load in COVID-19 patients during hospitalization
}

Yongjian Wu, Xiaomin Cheng (D), Guanmin Jiang, Huishu Tang, Siqi Ming, Lantian Tang, Jiahai Lu (D), Cheng Guo (D), Hong Shan (iD) and Xi Huang (iD

npj Biofilms and Microbiomes (2021)7:90; https://doi.org/10.1038/s41522-021-00262-z

Correction to: npj Biofilms and Microbiomes https://doi.org/ 10.1038/s41522-021-00232-5, published online 22 July 2021

In this article the author name Guanmin Jiang was incorrectly written as Guangmin Jiang and the affiliation 'Department of Clinical Laboratory, The Fifth Affiliated Hospital of Sun Yat-sen University, Zhuhai, Guangdong, China' was missing.

The original article has been corrected.

\begin{abstract}
(c) (i) Open Access This article is licensed under a Creative Commons Attribution 4.0 International License, which permits use, sharing, adaptation, distribution and reproduction in any medium or format, as long as you give appropriate credit to the original author(s) and the source, provide a link to the Creative Commons license, and indicate if changes were made. The images or other third party material in this article are included in the article's Creative Commons license, unless indicated otherwise in a credit line to the material. If material is not included in the article's Creative Commons license and your intended use is not permitted by statutory regulation or exceeds the permitted use, you will need to obtain permission directly from the copyright holder. To view a copy of this license, visit http://creativecommons. org/licenses/by/4.0/.
\end{abstract}

(c) The Author(s) 2021 